\title{
The Role of Biography as a Literary Form'
}

Dr. MacPherson is dean, School of Library Science, Drexel Institute of Technology.

As librarians you are likely to deal with biographies in several different ways. You select and order books representing this form of literature; you catalog and classify them; you recommend and lend them over the desk; you use biographies as reference tools for yielding detailed information when the occasion arises; and last -sometimes quite voluntarily-you even read them.

The following remarks are concerned mainly with the content of biographies, the style and form in which they are written, the approach of their authors. The subject will be treated more or less historically so as to show some of the changes that have developed in biographical writing from the earliest times up to the present. Certain centuries will be handled in detail whenever marked characteristics in biographical style are evident. There will also be an attempt to evaluate and compare some outstanding examples of biographies that have stood the test of time, as well as a few of our own day that seem likely to prove of lasting merit.

From this introduction it can be seen that the approach to the subject is to be from the point of view of the reader rather than that of the practicing librarian. It is possible, however, that an investigation and

1 Paper presented at the General Sessions Meeting, A.C.R.L., July I950, Cleveland, Ohio. analysis of trends in biography may heighten your interest and intelligence in the professional handling of works belonging to this class of literature.

Historically, the writing of biography may be said to go back to Plutarch's Lives in the first century A.D.; some critics would place the date a hundred years or so earlier. The discussion of biography as an art or distinct form of literature did not, however, become of much importance until the present century. Since World War I, the number of biographies produced annually has increased surprisingly, and the style of their writing has become more readable. Other changes relate to the more lifelike portrayal of the subjects, and to the more individualistic manner in which biographers handle their material. Writers and readers alike soon became aware of an awakening movement, and it was not strange that a considerable literature on the nature of biography should have arisen.

Beginning with the nineteen twenties, numerous publications have appeared, particularly in the United States and Great Britain, which deal with the history, analysis and criticism of the writing of biography. Some of these contributions assume the form of entire volumes. Others constitute introductory essays to selections from the works of several biographers. Still others represent articles in periodicals. A few that might be cited as noteworthy examples are: Wilbur L. Cross' An Outline of Biography; Andre Maurois' Aspects of Biography; Edgar Johnson's One Mighty 
Torrent; Edward H. O'Neill's A History of American Biography; J. M. Longaker's English Biography in the Eighteenth Century; Harold Nicholson's The Development of English Biography.

\section{Classification}

Most of these authors have attempted to classify existing biographies. The resulting divisions do not agree in every detail, chiefly because biography as a subject is so complex and so capable of being broken down in several directions. Nevertheless, a certain pattern develops which covers specimens that have been appearing during the past 2000 years.

As to amount of coverage, biographies may be classified as individual or collective. As to authenticity, they may be deemed scholarly or popular. As to authorship, they may be divided into autobiographies, or true biographies where the writer is a different person from the subject. As to point of view, they may be regarded as factual or critical, or as works combining both these elements. As to length of treatment, they may range from brief articles to comprehensive studies. Fictional biography and biographical fiction remain on the fringe because opinion differs as to where they belong.

Some types of literature which are generally included under the term biography are illustrated almost exclusively by specimens of autobiography. Aside from a few collections consisting of excerpts from the writings of several autobiographers, these types are regarded as peculiar to individual autobiography. They include such literary forms as diaries, journals, memoirs, letters, correspondence, reminiscences and confessions.

In both individual and collective biography an author may deal with his subject as a whole, or with some particular aspect on which he concentrates. Diaries and journals are likewise often confined to certain years of an author's life, though letters and correspondence may run from early in life until the very day of death.

The author of collective biography of ten finds it practical to select his subjects because of some point which binds them together, such as period or profession. This is true of Lytton Strachey's Eminent Victorians and of Eleanor S. Duckett's AngloSaxon Saints and Sinners.

Brief collective biographies of recent years have come to be known as "short biographies." Literally speaking, most collective biographies present brief treatments of several people, unless the author limits himself to two or three lives or extends his material to monumental proportions. Yet the number of volumes devoted to brief sketches of several people has been increasing steadily. A book published in 1935, by Marston Balch, Modern Short Biographies, emphasizes this trend.

Individual and collective biographies that deal with attainments of people in a critical or evaluative sense rather than in true biographical fashion are difficult to classify. Often it is a problem as to whether such books can be considered biography, as the chronological facts in a subject's life may be handled very incidentally. While more illustrations come to mind in the field of literature, examples may be found also among biographies dealing with artists, musicians, scientists and men of business.

\section{Authorship of Biographies and Autobiographies}

The part played by the author of a biography is considerable. His genuine interest in and knowledge of his subject, his style, his reputation as a writer, his objectivity, the age and country in which he lives, the relative importance of his subject in world 
events-all of these elements have important bearing on the book produced. Many excellent biographies have a narrow appeal because the person written about was renowned for too specialized a contribution. Not a few works, while important factually, remain almost unread because of their cumbersome style. Some books suffer and others gain in importance because the authors were related to or worked closely with their subjects.

Why does an author undertake to write a biography? Probably for as many reasons as people set out to write anything. The following would seem to outline the chief objectives: ( $\mathrm{I}$ ) to cover a definite need in the field; (2) to produce a by-product of intensive research already completed by an author, in the area of his specialty; (3) to answer public demand that he undertake the work because he has been deemed the best qualified person from one or several points of view ; (4) to use biography as a vehicle for propaganda; (5) to commemorate the anniversary of a subject's birth, death or offering to the world of some particular achievement; (6) to make money; (7) to launch or further a literary reputation; and (8) to fulfill an honest desire to increase the subject's importance by bringing him into the public eye.

Some of the qualifications of a biographer, such as ability to write and interest in his subject, have already been suggested. There are many others. Today, a scholarly biography must be well documented. This means that the writer must have read widely and have acknowledged in his work primary as well as secondary sources. If the subject has already been treated by other biographers, the new work is judged largely from the extent to which additional facts have been presented.

When the biography concerns a person who is still living or who has died recently, the author must contact friends and rela- tives who can furnish special information. This often involves much correspondence and considerable travel. Visits to the haunts of the biographee must also be considered whenever possible. Travel may also be involved in gaining access to manuscript collections and other special types of source material.

If the subject of a biography has become the center of controversy-involving personal immorality, questionable political standards, a secret marriage or a dozen other factors - the author must be careful in handling such details. Many lawsuits have resulted from the supposed defamation of a famous character. The biographer must also be on guard against publishing data from material which may have been shown to him confidentially.

In addition, a biographer must have perseverance, energy, optimism and discrimination. Needless to say, he must also possess the attributes of any research worker in a specialized field: background knowledge, accuracy, and in many instances, considerable ability at reading foreign languages. When he has at last finished his task, this paragon of writers should be prepared to hope for the best and prepare for the worst, in getting a publisher and having his book well acclaimed by readers.

\section{Qualifications of an Autobiographer}

Does a person who undertakes the writing of his own life history need to possess all the above-mentioned virtues? Perhaps not, but he must be able to write well and in an interesting fashion. Also, he must have something unusual to say, whatever his walk of life. A sense of humor likewise seems more necessary when a man is presenting himself in a book than when he is writing of others. Since many autobiographies are undertaken in old age or in late middle life, memory alone can seldom be relied upon. Reference to diaries, letters 
and certain texts may be necessary, as well as consultation with friends and relatives. This is particularly true when a man has led a very busy or varied life, or if he proceeds to delve into his ancestry. Of course there are instances where an autobiographer purposely misrepresents facts or omits necessary statements, but sooner or later such perversion of the truth will generally come to light.

Trends in Historical Development of Biographical $W$ ritings

To trace in entirety the historical development of the art of biography would prove an arduous, complicated undertaking. An examination of the literature of every civilized nation would be necessary, and then a concentration on all biographical texts available. Albert Britt's The Great Biographers is one of the few over-all outlines, and the work contains many gaps. A more adequate job has been done by writers who have focused on one period or one country, such as Donald A. Stauffer, in his The Art of Biography in Eighteenth Century England, published in 194I, and its earlier counterpart, English Biography before 1700 , published in 1930 .

The present author will aim to show trends from the earliest times up to the present, illustrating the different periods by mention of a few outstanding authors and titles. Beginning with the eighteenth century, selection becomes increasingly difficult, as the number of published biographies began to assume huge proportions. During the past decade, with hundreds of titles to choose from every year, one person's opinion as to outstanding writers seems as good as another's. The Publisher's Weekly for Jan. 2I, I950, states that the biographical titles published in the United States in 1949 showed an increase of 16 per cent over the preceding year. In 1948 there had appeared 460 new biographical titles and 53 new editions, making a total for the year of 5I 3 works. The year 1949 showed 526 new titles and 69 new editions, totaling 595 biographical titles in all. And these figures cover only American publications!

\section{Ancient Times}

In ancient times, before the fall of Rome in 476 A.D., biographical titles were not large in number. Yet if we begin with Plutarch, in the first century, A.D., certain prototypes of today may be found. Plutarch himself, through his Lives, presents an excellent example of collective biography. He covers 46 Greek and Roman leaders, arranging many of them in pairs, for the sake of contrast. Persons included represent such varied walks of life as emperors, statesmen, military leaders, philosophers and men of letters. Though many of his sources of information have been lost, a considerable number of the lives are documented, very often in the text itself. Plutarch had a modern conception of the difference between history and biography, and the fact that the individuality of a man must be emphasized in treating of him as a person.

Tacitus and Suetonius, who were both Roman historians of the second century, likewise proved themselves masters of the art of biography. Tacitus wrote one of the first individual biographies of note, when he produced the life of his father-in-law, Agricola. The latter emerges as a real individual, with a clear-cut personality. Moreover, Tacitus furnishes us with an excellent sketch of Britain under the Romans, so that Agricola is fitted into his particular background of place and time. The style of writing is also distinguished. Suetonius, in his Lives of the Caesars, produced another early example of collective biography. His subjects were for the most part insidious and he often exaggerated to the extent of becoming untruthful, so that 
the accounts of these emperors can best be described as lurid. Is this work the earliest example of the "debunking" variety of biography? Yet the style is straightforward and pleasing, as well as gossipy and humorous.

In 397 A.D. an early example of autobiography was written which came to be known as the Confessions of St. Augustine. The author, who was Bishop of Hippo in North Africa, was only 43 when he undertook the account of his life. The work consists of 13 books, of which the first ro depict the childhood and youth, the moral shortcomings and the inward struggles of the author. Prayers and meditations are often mixed with the account of his personal life. Here is an illustration of an autobiographer who does not shirk the telling of truth about himself, however sordid some of the details turn out to be.

\section{Mediaval Period}

There is then a gap of about four centuries, when the period of mediæval biography begins. For the most part, mediæval biographies were of two kinds, lives of the saints and lives of kings. The former were written largely for edification and record large numbers of miracles. The person written about dominates the scene, and there is seldom any attempt to write of the people with whom he was surrounded. Bede's Life of St. Cuthbert furnishes a better characterization than most lives of the saints, though Bede did not actually differentiate between history and biography. One unique point about St. Cuthbert's biography is the fact that Bede wrote versions of it in both prose and poetry.

Among the lives of kings, that of Charlemagne, by Einhard, may be chosen as a superior example. This author bridged the eighth and ninth centuries and had actually been a student in the Palace School of Charlemagne for many years of his life.
Personal acquaintance with his subject proved rather a disadvantage to Einhard, for Charlemagne's shortcomings are entirely overlooked and he is glorified as a sort of superman.

In England, about a century later, appeared the life of King Alfred, written by Asser, an English bishop. This study formed part of the author's chronicle of English history. While the book is highly eulogistic in tone, Alfred emerges as a man and not a saint.

Very few outstanding biographies appeared again until about the time of the Renaissance. Boccaccio's study of Dante, written in the fourteenth century, may be said to represent a new awakening, on the part of a biographer, in his subject. The work, while in prose, is written in poetic vein which is entirely in keeping with Dante's profession. Facts of Dante's life are given, his physical and mental characteristics are described, and there is some attempt at literary criticism.

\section{Renaissance}

During the sixteenth century there were compiled at least two notable individual biographies and one autobiography of merit. Of the individual biographies, oddly enough, one was written by Sir Thomas More about King Richard III of England, and the other was a work about More which was compiled by his father-in-law, William Roper. The famous autobiography was that of Benvenuto Cellini.

It is supposed that More's style and lifelike depiction of his subject were influenced by his thorough acquaintance with Tacitus. In any case, though the biography is well written, More shows himself to be out of sympathy with King Richard. More is often coldly ironic or scathing in his depiction of the king. Yet the characterization is realistic and indicates that More had considerable psychological insight. 
Roper's study of More is remarkable for its attention to detail in all the events of the latter's life. However, so far as style and exact characterization are concerned, the biography is uninteresting and scarcely does More justice. Roper must have been a man with limited humor and imagination, as he completely ignores More's wit and the lighter side of his nature. Was this work a hang-over from the mediæval period or a prototype of the general run of uninteresting individual biographies that was to prevail for the next three centuries?

Cellini's autobiography was written between 1558 and 1562. It has become a classic and has been translated into many languages by outstanding writers. Besides recording intimate details of an adventuresome, lustful life, Cellini succeeds in depicting the turmoil in the Italy of the period. It is a book such as only an artistic genius could have written, as it both attracts and repels by its spirit of revolt and bravado.

\section{Seventeenth Century}

The seventeenth century in England saw the rise of the diarists. As a form of autobiography, the diary is more intimate than most such writings, less continuous in style and likely to record the important things of the moment. There is no chance for reflection on the part of the author. None of what he puts down can be seen in retrospect. The two outstanding diarists of this period were Samuel Pepys and John Evelyn.

Pepys was a civil servant, with a post at the Admiralty. He was a member of the Royal Society and possessed a private library of several thousand volumes. $\mathrm{He}$ also had a zest for life and was devoted to the theatre. The diary covers a period of about nine and a half years, from 1660 to 1669. Pepys made much of the trivial, though he does record some important happenings of the time. The style is gay, on the whole, despite the entries of tragic events.

John Evelyn's work runs over a longer period, since he began making entries in 1641, when in his early twenties, and continued until almost the time of his death in 1706. He likewise was a public servant, and he traveled widely. While the facts that he records are often interesting and undoubtedly authentic, the style is for the most part dull and lacking in humor.

Sir Isaac Walton published a collection of five lives between 1640 and 1678 . His subjects were John Donne, Sir Henry Wotton, Richard Hooker, George Herbert and Robert Sanderson. At least three of these men were known to $\mathrm{W}$ alton personally. This perhaps accounts for the fact that the character of the biographer intrudes a little too much into the sketches. The style is rather monotonous, little or no humor is evident and a great deal of emphasis is put on theological matters. Nevertheless, Walton was a conscientious biographer, who took pride in his undertaking, and who could distinguish sharply between history and biography.

In France the seventeenth century represented the golden age in literature and in the prestige of the king and the court. Memoirs were kept by people high in society as well as by authors. Frequently these were not published until years afterwards. Such was the case with the memoirs of Saint-Simon, who lived well into the next century but started his recordings of court events and all that concerned the character and doings of Louis XIV and XV, with the year I693. The style is at times brilliant, but often tedious.

One letter writer of the century has gained renown far outside France. This was Mme. de Sevigné. The complete correspondence has been published in many volumes, and the people to whom she wrote included most of the literary and social 
lights of her time. However, the majority of her letters were written to her daughter, Mme. de Grignan, whose marriage meant removal to another part of France. While mother and daughter met at intervals, they were so unusually devoted that $\mathrm{Mme}$. de Sevigné sent almost daily accounts of the happenings at court or of the routines of existence at her country home. It is still a question as to whether these letters were written spontaneously or with a view to future publication. Their content shows the author to have been a well-educated woman, with keen political insight and great sophistication. The style is both charming and vivacious, with a certain lilt in the well-constructed sentences.

\section{Eighteenth Century}

The eighteenth century produced what is often called the greatest individual biography of modern times, Boswell's Life of Samuel Johnson. Careful reading of Boswell reveals the fact that this century, in Great Britain in particular, was a time of great biographical activity. Selection of names and titles that might be indicative of the best biographical trends in Europe is extremely difficult. The four men chosen represent different types of writers and illustrate several classes of biographical form: Voltaire, Goethe, Boswell and Johnson himself.

Voltaire, while generally classified as a philosopher, was also novelist, poet, dramatist and biographer. In the last-named category he produced at least two works which, alone, might rank him as a man of letters. They were his studies of Charles XII of Sweden and of Louis XIV of France. The first was printed in $I 73 I$, when Voltaire was still a young man; the latter appeared 2 I years later. The work on Charles was designed mainly as a portrait of an outstanding prince. The His- toire du siecle de Louis $X I V$ was, as its name suggests, planned as a delineation of French civilization of the seventeenth and early eighteenth centuries, quite as much as a character study of the Grand Monarch. Voltaire is, on the whole, kinder to Charles XII, though neither portrait is drawn without of prejudice. In each work there is an attempt to weigh the value of war, royal glory and the part played by the people in the life of the times. The work on Charles XII enjoyed an enormous vogue immediately after publication; yet it is the other title that is constantly pointed to as a masterpiece of the French language.

Goethe's Dichtung und Wahrheit was begun in $181 \mathrm{I}$, when the poet was about 62 years old. Part IV, which was the last to be completed, carried his life only to I 775, so that the book is an autobiography only of the first 26 years of the author's life. For the most part, Goethe relied on his memory for the various incidents related. He did, however, consult members of his family and a number of historical works. The book is a fascinating account of Goethe's ancestry, childhood, love affairs, travels, education and search for a profession. Some of the important men who figured in the Sturm und Drang period are characterized, and many of the trials and joys of the compilation of his two early works, Werther and Goetz von Berlichingen, are recounted. Undoubtedly, there are some episodes which have been colored; again, some incidents have been omitted. Yet, taken as a whole, the work presents an intimate account of the growing pains of a great artist. The style is simple, engaging and often amusing.

Samuel Johnson was himself a biographer of note. Much of his work appeared in journals or as prefaces to volumes written by other authors, but at least one title must be acclaimed as an outstanding example of 
collective biography. This is his Lives of the English Poets, which is comparatively free of the encumbrances of Johnson's rather heavy style. Many of the poets had been known to him personally, their works had been read thoroughly and he had spared no effort in assembling intimate facts. Among the names included, Milton, Pope and Gray are still recognized as important, but large numbers of forgotten poets are represented. On the whole, Johnson dealt fairly with his subjects. A notable exception is in the case of Gray, whom he was always wont to criticize severely.

Boswell's Life was an innovation in that it illustrates the conscious effort of a biographer to entwine himself with the life of his subject. Actually, Boswell never met Johnson until I 763 , when the latter was 54 years of age, and already an acknowledged man of letters. Facts of his subject's early years were gathered by Boswell from Johnson himself, mutual friends and some written sources. It is therefore natural that four or five times as much space should be devoted to the last 20 years of Johnson's life. The presentation is complex, in that at all meetings with Johnson, Boswell records at length Johnson's sayings and his arguments with those present. Interspersed with the details of the actual meetings are the texts of letters written by and to Johnson, and a chronological account of Johnson's literary efforts and personal actions. Not to be overlooked are the descriptions of a large number of miscellaneous friends belonging to Johnson's circle. Reynolds, Garrick, Goldsmith, Burke, King George III, mingle with obscure apothecaries and young students. Boswell had the highest opinion of Johnson, both as man and author, yet he frequently sprays his manuscript with adverse criticism. Thus he escaped the pitfalls of many biographers who become only hero worshippers.

\section{Nineteenth Century}

With the nineteenth century, the writing of biography appeared to become the habit of almost anyone who could undertake the compilation of a book. It is this century which introduced the United States as an important source of biographical publications. This era also saw the birth of what may be called the democratization of biography, because of the growing tendency to extend biographical coverage to persons in every walk of life. Another innovation was the starting of series, under able editors, of individual biographies to be written by outstanding authors. Thus there developed the American Statesmen Series, and the English Men of Letters and American Men of Letters Series. Still another trend is to be seen in the tendency for many different writers to undertake the biography of some noteworthy person. This resulted in the building up of a veritable literature on such men as Napoleon, Washington, Lincoln, Dante and Goethe, with wide variety in treatment of the subjects, search for new sources, and specialized handling of only one phase of a man's life.

Selection of eminent American biographers might be made on the basis of writers who were pioneers in this field or who made notable contributions to one particular class of biography. For these reasons it seems well to cite Parson Weems, Washington Irving, Jared Sparks and James Parton.

Parson Weems has gained renown not as the earliest prolific American biographer, but as the forerunner of writers of the modern fictionalized biography. His subjects-William Penn, Washington, Franklin and General Francis Marion-were all of interest to the world for which he wrote, but Weems drew upon his imagination to such an extent that what was fact and what was fiction was not easy to ascertain.

Washington Irving, perhaps better 
known for his writings in other fields, produced a series of four early essays on American naval heroes of the War of 1812 . Far more important, however, was his History of the Life and Voyages of Christopher Columbus, printed in 1828 , which is even now acclaimed as one of the best biographies of that voyager. The style is Irving's best, and while there are no footnotes, the author has gone to infinite trouble to inspect the best source material. Irving also contributed notable works on Mahomet, Goldsmith and Washington.

Jared Sparks, though preeminently known as a historian, produced biographies of John Ledyard and Gouverneur Morris, in 1827 and 1832 respectively. These are well written and still consulted today. When he published the Works of Benjamin Franklin, with Notes and a Life of the Author, Sparks made a notable contribution to American biography by instituting the vogue for the combined life and works of a man. He also established a precedent in documenting his material from original sources. In 1847 Sparks produced an example of the combination of life and letters, when he published the Life and Correspondence of Joseph Read, of revolutionary fame.

Probably the earliest professional biographer in America was James Parton, who started with a life of Horace Greeley in I 855 and continued publishing individual and collective biographies for the next 30 years. Burr, Jackson, Franklin, Voltaire and John Jacob Astor were among the subjects for his individual biographies. As for his collective biographies, perhaps his earliest, Famous Americans of Recent Times, is the most commendable. Parton's style was not particularly polished, but he had a wide range of interest in people, and his character sketches are vivid and, for the most part, accurate.
One name stands out above all others for nineteenth century France; that is SainteBeuve. He still remains on the lists of the renowned literary critics of any age and retains stature among the best writers of collective biography. Three works of his, one of which was devoted to celebrated women, deal with prominent literary figures of France and other countries. His criticism is biting, though frequently justified, and his analysis of character seldom to be equaled.

Biographers in nineteenth century England were among all ranks of people. Probably Macaulay, Carlyle and Thackeray would be included in any selection to be made. Macaulay becomes notable not only as the author of the Essay on Milton but also because of his Life and Letters, which were edited by a nephew, Sir George Trevelyan. The selection of material to be included in the latter work was of course done by Trevelyan, but the letters themselves show a rare insight into the working habits of a great historian.

While the Essay on Burns is generally considered Carlyle's masterpiece among biographical items, his Heroes and Heroworship is a splendid example of collective biography which aims to cover all countries and all periods. Here, his groupings of heroes are at once logical and ingenious; the criticism is usually just; the portraits are brief but lifelike.

Two letter writers of note, Stevenson and Henry James, belong properly to the nineteenth century, though James's correspondence was not published until a few years after his death, which occurred in 1916. Since Mme. de Sevigné of the seventeenth century, there had probably been no more compelling correspondents than Stevenson and James. Both knew many people, lived in several countries and were voluminous letter writers. Stevenson's let- 
ters are more personal and humorous; he wrote a great deal about himself. The correspondence of James reveals a kindly man who, as a rule, devotes far more time to the affairs of the friend to whom he is writing than to his own personal problems. It can be said that James's letters contain more substance, while Stevenson's exhibit more charm. While many people believe that Stevenson's letters were written with a view to future publication, each letter of James appears to be quite spontaneous.

\section{Twentieth Century}

In the twentieth century a revival of biography, and perhaps its reformation, seems to have taken place. Mention has already been made of the more humanized biography which came into being after World War I. Lytton Strachey is often credited with its inception, both because of his own studies of famous people and his ideas about biography as a literary form. There were, however, many others who played a role in the popularization of biography, among whom might be mentioned that indefatigable writer, Emil Ludwig, and one author of the "debunking" type of study, George S. Hellman.

Before the advent of popular biography on a large scale, there was published privately in 1906 a work which has been acclaimed one of the greatest of modern autobiographies. This was The Education of Henry Adams, by Henry Adams. It is written in the third person, and the word "education" implies the author's adjustment to the world in general. It is a social, political and literary account of the author's life and the contacts that he made. Even people who are not particularly interested in education in the narrow sense are enthralled by this book.

Among the hundreds of new biographies that have been published during the past year, this author has read at least 25 titles. These have represented every type of individual and collective biography, including letters, memoirs and diaries. Some, like the voluminous autobiography of Sir Osbert Sitwell, and the equally extended study of Washington by Douglas S. Freeman, started publication some time ago and are as yet unfinished. These two works, though fascinating and crowded with a variety of personalities, cannot be judged fairly until completion. The former seems a bit pedantic in style. The latter is so heavily documented that it requires two readings to grasp all the implications. Yet each study is likely to become a landmark in the history of biographical undertakings in England and America.

Several volumes of individual biography encountered have proved heavy in style, ill planned, or unsatisfactory as to accurate coverage of the subject. On the other hand, the author has read one comprehensive life of a philanthropist that was superbly done. Among collective biographies she recalls with pleasure a volume devoted to contemporary musicians, and Tharp's The Peabody Sisters of Salem. Are we entering another phase of biographical compilation, in which quality is being sacrificed to quantity and in which documentation is playing too heavy a part?

There is no evidence of striking innovation as to the forms in which contemporary biography is now being cast. We still have with us the counterparts of samples that have been offered during the past 2000 years. One thing, however, appears certain -there seems no fear that biography will disappear as a separate form. The novelists and the historians may attempt subtle mergings, but the role of biography remains as the literature of personality-the truthful portrayal of the characters of real men and real women. 